Article

\title{
Perspectives and Attitudes of Forest Products Industry Companies on the Chain of Custody Certification: A Case Study From Turkey
}

\author{
Ahmet Tolunay ${ }^{1, *}$ and Türkay Türkoğlu ${ }^{2}$ \\ 1 Süleyman Demirel University, Faculty of Forestry, 32260 Isparta, Turkey \\ 2 Muğla Sitkı Koçman University, Köyceğiz Vocational School, Program of Forestry and Forest \\ Products, 48800, Muğla, Turkey; E-Mail: turkayturkoglu@mu.edu.tr \\ * Author to whom correspondence should be addressed; E-Mail: ahmettolunay@sdu.edu.tr; \\ Tel.: +90-246-2113952; Fax: +90-246-2371810.
}

Received: 27 December 2013; in revised form: 10 February 2014 / Accepted: 11 February 2014 / Published: 20 February 2014

\begin{abstract}
The perspectives and attitudes of the companies of the forest products industry operating in the fields of solid wood products, pulp, paper and paperboard products, engineered wood products and furniture manufacturing in Turkey on the chain of custody certification system and certified forest products were investigated. Within this scope, face-to-face interviews were conducted with the managers or owners of 177 companies. The data were obtained by using the questionnaire technique. The research methods included descriptive statistics, one-way analysis of variance and the Duncan test. As a result, it was detected that there are differences in the perspectives and attitudes towards the chain of custody certification system of the companies operating in the four main branches of the forest products industry in Turkey. It was revealed by this survey that chain of custody (CoC) certification was known mostly by the companies operating in pulp, paper and paperboard companies. The certification most demanded is the Forest Stewardship Council (FSC) CoC certification, with a share of $15 \%$; and Programme for the Endorsement of Forest Certification (PEFC) CoC is demanded by $2 \%$ of companies.
\end{abstract}

Keywords: sustainable forest management; forest certification; forest products industry; chain of custody; Turkey 


\section{Introduction}

The environmental movement has emerged as a response to society's concerns about the sustainability of Earth's natural resources [1]. 'Environmental awareness' has a major influence on many people in their daily life, including the way consumers buy and use products [2]. There is an increasing demand in the developed world for environmental certification in this new globalized era [3]. Environmental certification is a form of environmental regulation and development where a company can voluntarily choose to comply with predefined processes or objectives set forth by the certification service [4]. Most certification services have a logo (commonly known as ecolabel) which can be applied to products certified under their standards. This is seen as a form of corporate social responsibility ${ }_{2}$ allowing companies to address their obligation in order to minimize the harmful impacts to the environment by following voluntarily a set of externally measured objectives [5].

Forest certification is one of the environmental certifications that was initially advanced by environmental groups as a response to the consequences of deforestation and forest degradation [6,7]. Although the principle of sustainability in forestry has a long history, Forest certification was the result of a series of events dating back to the 1960s that aimed to address the degradation of natural resources [8]. Sustainable forest management (SFM) constitutes the basis of forest certification. SFM has become the dominant paradigm for discussing forest management and protection in the world. SFM addresses economic, ecological and social components of forestry. Several international SFM Criteria and Indicator processes and accords address SFM in temperate and tropical forests. These generally include broad criteria that indicate the principles for forest management and indicators that can be used to measure and track the status of the world's forests at the national level, or in some cases, at the forest management unit level [9]. SFM and forest certification have been developed in order to measure forest management, environmental protection and social benefits from forest ownership and forest practices at the forest management unit or stand level [6].

There are several forest certification organizations in the World, the most well-known are the Forest Stewardship Council (FSC), the Programme for the Endorsement of Forest Certification (PEFC), the Tropical Forest Trust (TFT), the Indonesian Ecolabelling Institute (LEI) and the International Tropical Timber Organization (ITTO). They are recognized forest certification schemes dedicated to promoting responsible SFM by means of regional and national standards.

FSC was founded in 1993 as an international non-profit, non-governmental and membership-based organization whose Principles and Criteria for Forest Stewardship are used as the basis for independent, third-party certification of forest management operations around the world [10].

PEFC was founded in 1999 in response to the specific requirements of the owners of small forests, as an international umbrella organization providing independent assessment, endorsement and recognition of national forest certification systems. It works by endorsing over 30 national forest certification systems, some of which are the American Tree Farm System (ATFS) and the Sustainable Forest Initiative (SFI) in the United States; Canada's Standards Association system (CSA); Brazilian Forest Certification Programme (CERFLOR); Malaysian Timber Certification Council (MTCC); and Indonesian Forestry Certification Cooperation (IFCC) [11].

PEFC responded to the need for a mechanism enabling the independent development of national standards tailored to the political, economic, social, environmental and cultural realities of the 
respective countries, while ensuring compliance with internationally-accepted requirements and global recognition at the same time [11].

The forest certification system consists of two major components, namely the forest management certification and the chain of custody certification (CoC) [12]. Forest management certification is an important strategy for improving forest management and the conservation of forests, because it ensures that products come from well-managed forests which provide environmental, social and economic benefits. $\mathrm{CoC}$ certification allows companies to label their products, which in turn enables consumers to identify and choose products that support responsible forest management [10].

Labeling systems provide producers with an instrument to communicate the environmental performance of their products and thus influence the purchasing attitude of consumers. Consumers benefit from this upon an easily accessible assessment of the environmental attributes of a product or service [13]. CoC provides a response specific for the forestry sector. It is a voluntary program based on the belief that consumers of forest products are likely to prefer products from organizations committed to protect the natural environment. The main aim of forest certification is to improve forest management by providing participating companies with marketing incentives [14]. It is unclear whether certification will become a requirement for forestry companies to enter into specific foreign markets or more environmentally-sensitive markets, such as the European and North American markets [7].

The forest certification is important for companies in the forestry sector because they show that they have improved forest management in place which encourage environmental responsibility such as the sustainable use of forests. This, in turn, becomes a marketing tool to end consumers who are very aware of environmental issues. The certifications improve the public image, prestige, and community relations of companies who have them. From this they can gain market access, charge premium prices, and have a competitive advantage over other companies who do not have them. In other words, the certifications make good business sense.

The forest products sector has made rapid progress in terms of the import and export values within the last decade in Turkey which constitutes a bridge between Europe and Asia [15]. Concordantly, the market of certified forest products (CFPs) began to emerge. The company of the CoC certification system in the Turkey's forest products industry has been initiated as a result of the demand of purchasing companies for CFPs especially in exported forest products. It has also been initiated due to the fact that most of the forest products imported especially from European countries had certificates as well [16].

This study tried to explain the development of the CoC certification system in Turkey and the perspectives and attitudes of forest products companies operating in the fields of Solid Wood Products (SWPs), Pulp, Paper and Paperboard Products (PPs), Engineered Wood Products (EWPs) and Furniture manufacturing. The situation in the companies operating in these four manufacturing fields was addressed individually and presented the differences of view.

\subsection{The Forestry Sector in Turkey}

Turkey has about 22 million hectares of forest area, 99\% of which is state owned. This consists of $27 \%$ of the country's land area and is managed by the General Directorate of Forestry (OGM) which is a governmental body. Turkey's forests produce 13 million $\mathrm{m}^{3}$ of round wood annually. This 
production meets about $75 \%$ of the domestic round wood consumption. Private forests and agricultural land provide 3 million $\mathrm{m}^{3}$ of industrial wood while the remaining 1.5 million $\mathrm{m}^{3}$ of demand is met by imports [17].

Turkey's forest products industry is controlled completely by the private sector. Fiberboard, particle board, furniture, paper and packaging, wood panels, assembled parquet panels, timber and builders' joinery are the main forest products in Turkey. Wood processing industries are mainly composed of small companies although there are a few medium-scale companies. Many small-scale furniture companies and sawmills, with labor-intensive technologies, provide employment and income opportunities in poor, rural areas and, as such, the sector carries importance with respect to employment creation and reducing regional differences in income distribution [18].

Turkey's large milling and wood manufacturing industry is in a position to supply wood products to regional markets in the Middle East, particularly those countries that lack a wood manufacturing sector of their own. Turkey is also in a competitive position to supply semi-processed wood products and furniture to the EU as a result of its relatively lower labor costs. Turkish forest product based industries, such as the panel and furniture industries, have increased their capacity over the last decade, allowing them to take advantage of these regional opportunities [19].

In case of Turkey's forest products trade, softwood and hardwood logs are imported from Russia and Ukraine. Turkey's major furniture export markets include Germany, France, Iran, Iraq and the Turkic Republics. Turkish paper producers import wood pulp as they do not produce it themselves. The Turkish forest products industry has grown in each product type through new investments made in last decade.

\subsection{Chain of Custody Certification in Turkey}

The certification of products dates back to the tropical timber wars of the late 1980s. When a suggested boycott of tropical timber led to the realization that the success in such an effort would probably only devalue tropical forests, the concept of identifying and rewarding responsible forest management was born [20]. By mid 1990s forest certification and $\mathrm{CoC}$ certification had become reality, first with the introduction of FSC certification and then with the development of a host of reactionary programs [19].

Forest certification has gained momentum as a market-based conservation strategy in tropical forest countries. Certification has been promoted in order to enhance forest management in countries where governance capacities were insufficient to adequately manage natural resources and enforce pertinent regulations, given that certification relies largely on non-governmental organizations and private businesses [21]. The original goal of certification was to protect tropical forests. However, today, certified logging operations exist mostly in boreal and temperate environments [22].

Environmental certification of forest products and forestry practices is fast becoming one of the most pressing issues faced by the forest products industry. In response to environmental concerns, some environmental organizations, retailers and wood products companies are developing standards to encourage consumers to purchase wood originating from certified sustainable forests [23]. Assuring the sustainable use of a forest resource is the first step in ensuring the quality of use of our forest resources. In the forest products value chain, the original wood resource is subjected to a series of 
processing steps, starting with trees in the forest and ending with final wood products, such as furniture, kitchen cabinets or floors in use by end customers. The tree and the resulting semi-finished and finished products typically change ownership several times before reaching the end customer. To be able to capture the benefits of sustainable management of our forest resources through, among other things, higher demand for such products, higher prices or a better corporate image and the source of the material needs to be certified to allow customers to have verifiable information about the origin of the material [1].

The CoC certification in Turkey was initiated and expanded completely under the guidance of companies (in a market-based manner). The request of a CoC certification from the company that tried to sell products to some European countries or the preference of certified products, as a matter of principle, by international companies operating in Turkey, forced companies in our country to manufacture or sell certified products. For instance, the request of the presence of either an FSC or PEFC certification in labels and paper packages by an Italian-origin apparel company enabled the paper importer operating in the sector as well as the printing house processing the paper from the importer or the label company to be included into the $\mathrm{CoC}$ certification system as well [16]. However the forest products industry in Turkey has had rapid improvement, thus it has been thought that the number of the certificated companies will increase and they will produce CFPs for domestic market. Figure 1 shows the numbers of companies with a CoC certification in Turkey.

Figure 1. Number of companies with a chain of custody $(\mathrm{CoC})$ certification in Turkey.

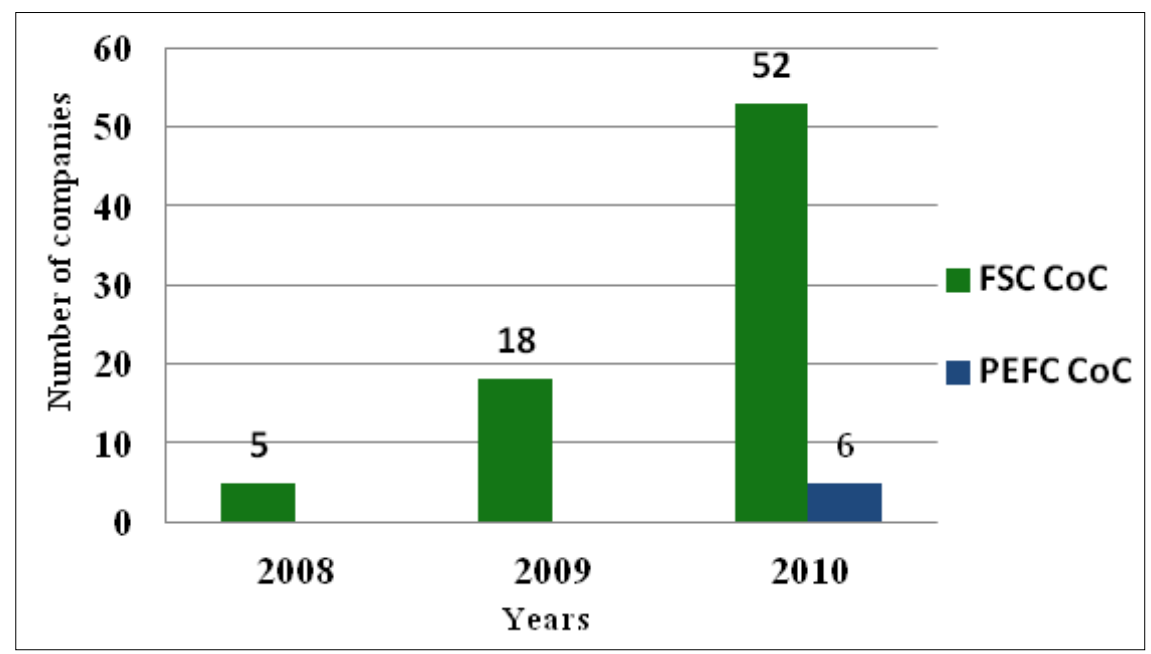

(Source: FSC and PEFC Database, 2011).

Forest products are imported to Turkey from many countries. In the interviews conducted with the representatives of importing companies it was reported that FSC or PEFC CFPs were sent from supplier companies. It was observed that many products imported from Ukraine, Latvia, Austria and Brazil as semi-finished product such as timber, plywood, planks and OSB (Solid wood products and engineered wood products) came from certified companies.

Considering this topic from the perspective of paper and paper products importers, it was detected that many of the specialized papers imported from the US, Europe and Scandinavian countries were certified. It was understood that some importing companies had an FSC certification and imported FSC certified paper products. They marketed these to companies which operated in the certified label or 
paper packaging sector. Figure 2 indicates the numbers of $\mathrm{CoC}$ certificatied companies according to operating fields.

Figure 2. Fields of operation of $\mathrm{CoC}$ certified companies in Turkey.

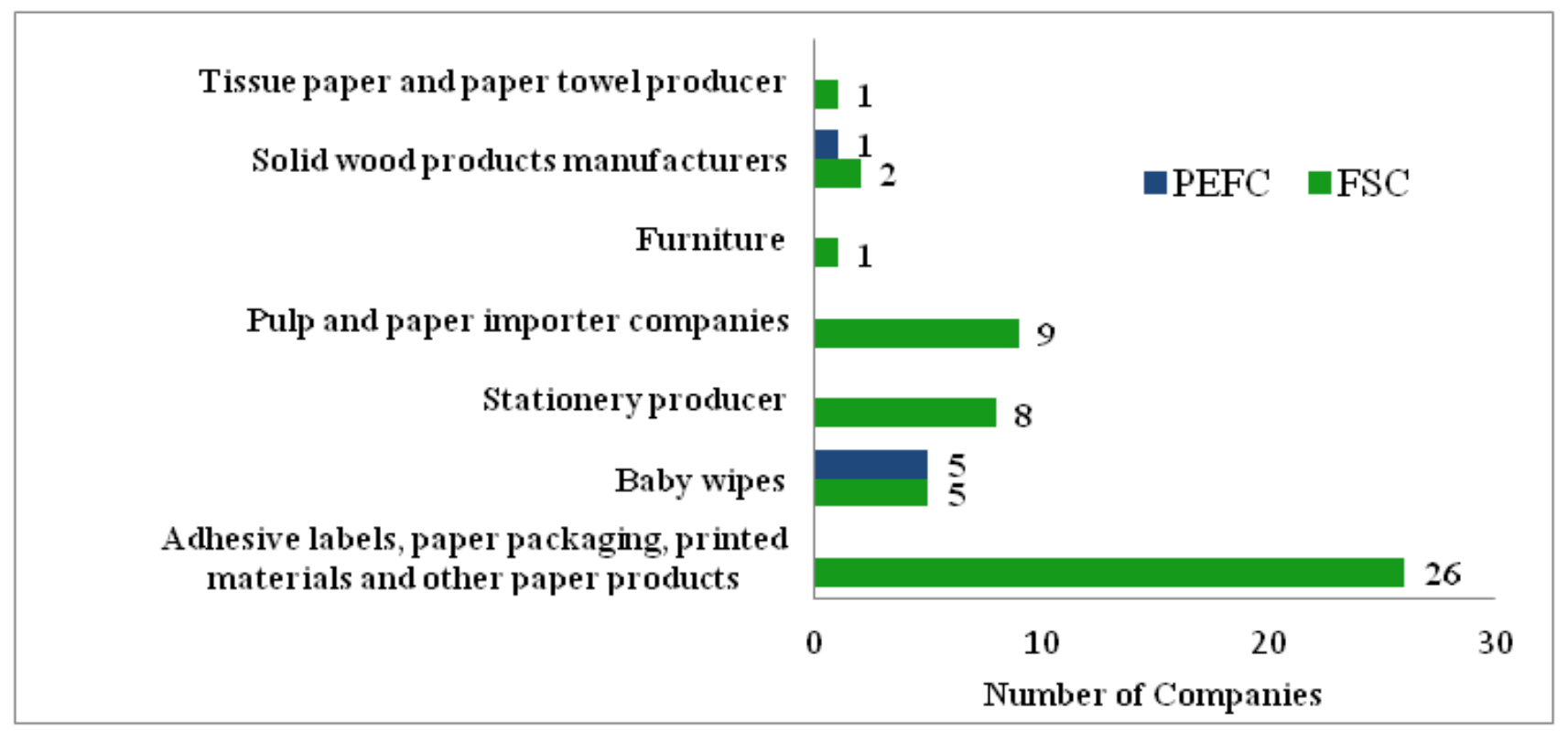

(Source: PEFC and FSC Database, 2011).

This information was obtained from supporting documents, the FSC and PEFC database and the observation of Turkey's forest products Industry.

\section{Methods}

The data for this study were collected during the period spanning from fall 2010 to spring 2011 via face-to-face surveys and structured interviews conducted with business owners or managers of companies to gain the views and attitudes with regard to $\mathrm{CoC}$ certification of the forest products sector in Turkey. The objective of this draft questionnaire was developed by using academic literature and reports about forest certification, related forest certification documents and contacting researchers in universities focusing on forest certification. The questionnaire was obtained pursuant to the pre-application and conduct of relevant adjustments. It consisted of two sections and contained 11 questions on two pages. The questionnaire included a brief description of forest certification and $\mathrm{CoC}$, questions about companies profile in the first section and questions in second section were asked to assess views and attitudes on the $\mathrm{CoC}$ certification of the forest products sector in Turkey.

The population consisted of 1800 forest products companies (importing and exporting companies in Turkey) listed in Turkey's Undersecretariat of Foreign Trade Database. The survey was conducted face-to-face, with 177 randomly selected forest products companies. Thus, we obtained a sample and calculated $95 \%$ confidence level and $7 \%$ margin of error by means of sample size calculator [24]. The Cronbach alpha coefficient of the whole questionnaire was 0.75 . Descriptive statistics were used to analyze the data and one-way analyses of variance $(\alpha=0.05)$ were used to measure significant differences between means [25]. When statistical significance $(\alpha=0.05)$ was found, all pairwise comparisons were tested using the Duncan's method [26]. The notion of the presence of a difference 
between the perspectives and attitudes of the companies operating in the four main branches of the forest products industry in Turkey towards the $\mathrm{CoC}$ certification system constitutes the basis of the main hypothesis of this survey.

\section{Results}

The survey was conducted with 177 companies of the forest products industry in Turkey. Firstly information was given about the general profile of the companies (see Figure 3). Secondly, companies' answers to the questionnaire descriptive statistics about mean and standard deviation were explained (see Table 1). Then, one-way analyses of variance were used to measure significant differences between means. Operating branches were chosen as a factor at one-way Anova analysis. The differences of the answers to the questions of the companies were found by this analysis (see Table 2). The Duncan test was done to determine which group caused the differences (see Tables 3 and 4). Lastly, the companies of the forest products industry were separated under the four main groups considering the sub-sector branches. The percentages of the answers given to the questionnaire by these sub-sector groups were included to eliminate the different views of the companies in a detailed way (see Figures 4 and 5). The crosstabs of descriptive statistics in statistical program were used during this process. Thus, the differences resulting from the company profiles were focused on. Figure 6 and Figure 7 show the situation about certificate in the forest products market in Turkey.

\subsection{General Company Profiles}

The companies included in the survey operate as manufacturers in the following fields in the forest products industry in Turkey: SWPs 34\% (60 participants), PPs 30\% (53 participants), EWPs 6\% (10 participants) and furniture 30\% (54 participants). Figure 3 summarizes participant companies' profile information.

Figure 3. Forest products sector branches by participants $\left(\mathrm{n}_{\mathrm{total}}=177\right)$.

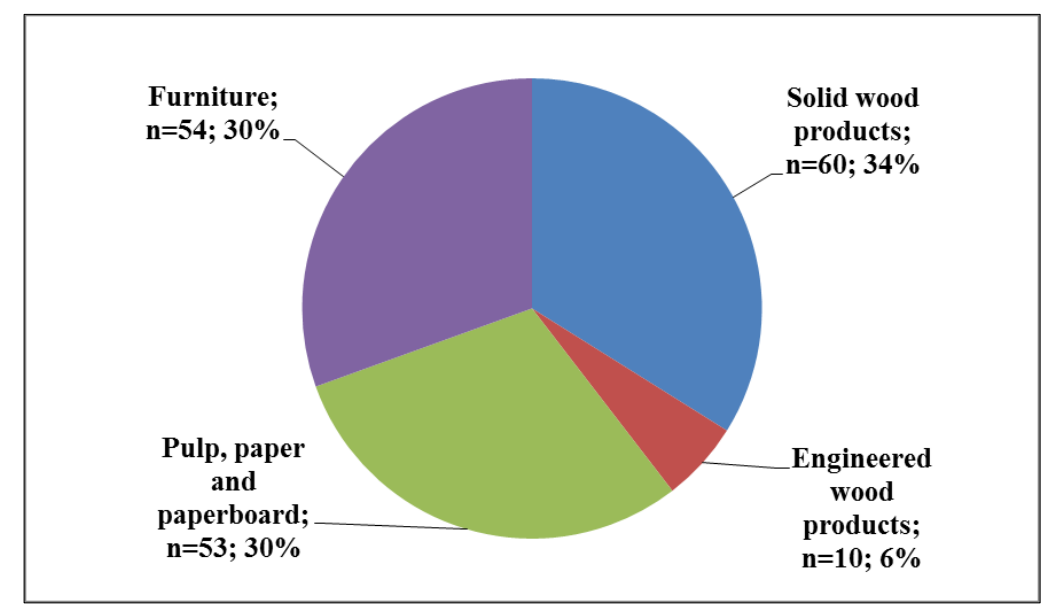

\subsection{Descriptive Statistics for Statements Made to Companies}

The summary descriptive statistics for statements made to companies in Table 1 indicate the average (Mean) and standard deviation (SD). 
Table 1. Descriptive statistics for statements made to companies.

\begin{tabular}{lccc}
\hline \multicolumn{1}{c}{ Statement } & N & Mean $^{\text {a }}$ & SD \\
\hline Companies which have heard about or know CoC & 177 & 1.4237 & 0.4955 \\
$\begin{array}{l}\text { Companies which think CoC is necessary in FPs } \\
\text { Companies which want to use CFPs }\end{array}$ & 177 & 1.1017 & 0.3031 \\
$\begin{array}{l}\text { Companies which are willing to pay a premium } \\
\text { for CFPs }\end{array}$ & 177 & 1.0791 & 0.2706 \\
$\begin{array}{l}\text { Companies which believe that CoC increases } \\
\text { sales }\end{array}$ & 177 & 1.4011 & 0.4541 \\
$\begin{array}{l}\text { Companies which believe that it will positively } \\
\text { affect the FPs industry }\end{array}$ & 177 & 1.0791 & 0.2706 \\
$\begin{array}{l}\text { Companies which experience sales problems due } \\
\text { to the lack of CoC }\end{array}$ & 177 & 1.8418 & 0.3659 \\
$\begin{array}{l}\text { Certificates requested from companies } \\
\text { b }\end{array}$ & 177 & 4.2373 & 1.8122 \\
\hline The mean value reported of participants who responded "yes" or "no". ${ }^{\mathrm{b}} 6$ point scale used (see Figure 7).
\end{tabular}

\subsection{Results of One-Way ANOVA and the Duncan tests}

The results of the simple variance analysis conducted according to the fields of activity of the companies are presented in Table 2.

Table 2. The result of one-way ANOVA and differences of views

\begin{tabular}{ccccccc}
\hline Dependent Variables & & $\begin{array}{c}\text { Sum of } \\
\text { Squares }\end{array}$ & df & $\begin{array}{c}\text { Mean } \\
\text { Square }\end{array}$ & F & P \\
\hline \multirow{2}{*}{$\begin{array}{c}\text { Companies which have } \\
\text { heard about or know CoC }\end{array}$} & Between Groups & 7.83 & 3 & 2.610 & 12.75 & $0.000^{*}$ \\
& Within Groups & 35.39 & 173 & 0.205 & & \\
\hline \multirow{2}{*}{$\begin{array}{c}\text { Total } \\
\text { prempanies willing to pay a }\end{array}$} & Between Groups & 1.66 & 3 & 0.556 & 2.77 & $0.043^{*}$ \\
& Within Groups & 34.63 & 173 & 0.200 & & \\
\hline
\end{tabular}

$* p<0.05$, significant at a confidence interval of $95 \%$.

According to these results, some differences of view were detected in terms of the companies which have heard about or know $\mathrm{CoC}$ or companies willing to pay a premium for CFPs according to their fields of activity.

As a result of the Duncan test conducted for the purpose of identifying the sub-sector from which the differences were derived according to these results, furniture manufacturers and SWPs manufacturers were in the same group as they were in the field with the lowest knowledge level about the $\mathrm{CoC}$ certification. This caused the biggest reason for the emergence of this difference. Meanwhile, PPs manufacturers constitute the group that knows best the CoC certification system.

The field of activity with the least willingness to pay a premium for CFPs among the companies was constituted of SWPs manufacturers. A great majority of the companies in their fields of activity recorded that they were willing to pay a premium for CFPs. 
Table 3. Result of Duncan test for companies heard about or know CoC.

\begin{tabular}{lcccc}
\hline Activity fields of & \multirow{4}{c}{ Subset for alpha $=0.05$} \\
\cline { 3 - 5 } companies & & 1 & 2 & 3 \\
\hline PPs & 53 & 1.1509 & & \\
EWPs & 10 & 1.3000 & 1.3000 & \\
SWPs & 60 & & 1.4500 & 1.4500 \\
Furniture & 54 & & & 1.6852 \\
Sig. & & 0.237 & 0.234 & 0.063 \\
\hline
\end{tabular}

Table 4. Result of Duncan test for companies willing to pay a premium for certified forest products (CFPs).

\begin{tabular}{|c|c|c|c|}
\hline \multirow{2}{*}{$\begin{array}{l}\text { Activity fields of } \\
\text { companies }\end{array}$} & \multirow{2}{*}{$\mathrm{N}$} & \multicolumn{2}{|c|}{ Subset for alpha $=0.05$} \\
\hline & & 1 & 2 \\
\hline EWPs & 10 & 1.1000 & \\
\hline PPs & 53 & 1.2264 & 1.2264 \\
\hline Furniture & 54 & 1.2407 & 1.2407 \\
\hline SWPs & 60 & & 1.4167 \\
\hline Sig. & & 0.289 & 0.151 \\
\hline
\end{tabular}

Considering these results, it was determined that there are differences of view with regard to the $\mathrm{CoC}$ certification system among the companies. Thus, our research hypothesis proved to be right and it was detected that there was a difference in the perspectives and attitudes towards the CoC certification system of the companies operating in the four main branches of the forest products industry in Turkey.

\subsection{Perspectives and Attitudes of the Companies on the Chain of Custody}

In this section, the answers' percentages of the four branches in the company profiles were used separately by means of the crosstabs. This made us focus on the details of the research.

None of the companies encompassed by this survey have a $\mathrm{CoC}$ certification. Moreover, it was detected that $42 \%$ of these companies are not informed at all about the $\mathrm{CoC}$ certification. Thus, the CoC certification is known mostly in the PPs manufacturers, with $85 \%$ awareness, while it is known least in the field of furniture manufacturers with only $32 \%$ awareness. As this survey was conducted in the form of a face-to-face questionnaire, relevant information was conveyed with a factsheet about the $\mathrm{CoC}$ certification. Consequently, it was asked whether such a certification was required for forest products and $90 \%$ of the companies stated that this was necessary. It was indicated by $92 \%$ of the companies that they would prefer certified products in the procurement of raw materials. The distribution of these findings according to the field of activity is provided in Figure 4.

It was reported by $70 \%$ by the companies that they would be willing to pay a premium for CFPs. Sixty percent of the companies with a $\mathrm{CoC}$ certification believe that their sales will grow due to the certificate. Meanwhile, 92\% believe that the inspection of their companies by certification bodies supplying $\mathrm{CoC}$ certification will have a positive impact on the forest products industry. The data relating to these findings are provided in Figure 5. 
Figure 4. Knowledge of the CoC certification and willingness to use CFPs by companies.

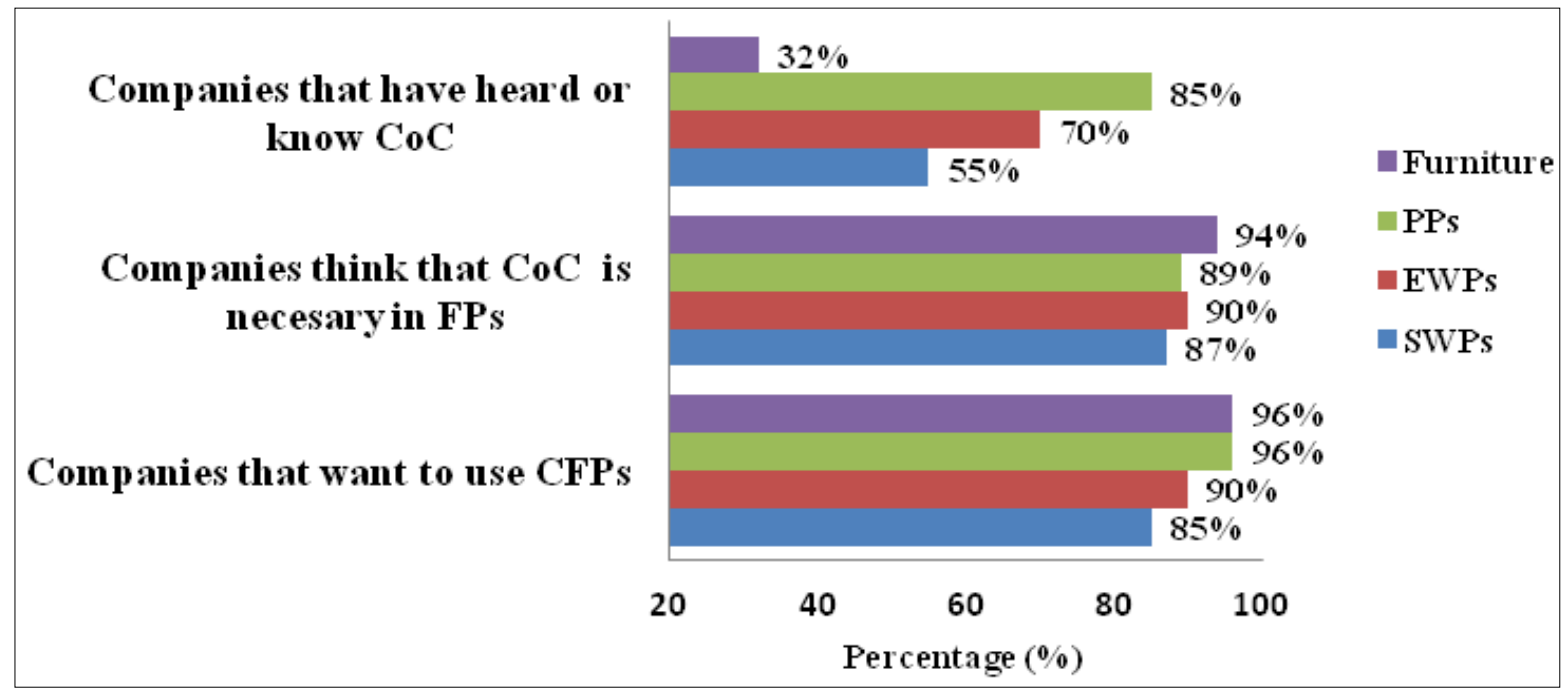

Figure 5. Willingness to pay a premium for CFPs and the effects of $\mathrm{CoC}$ on sales and the industry.

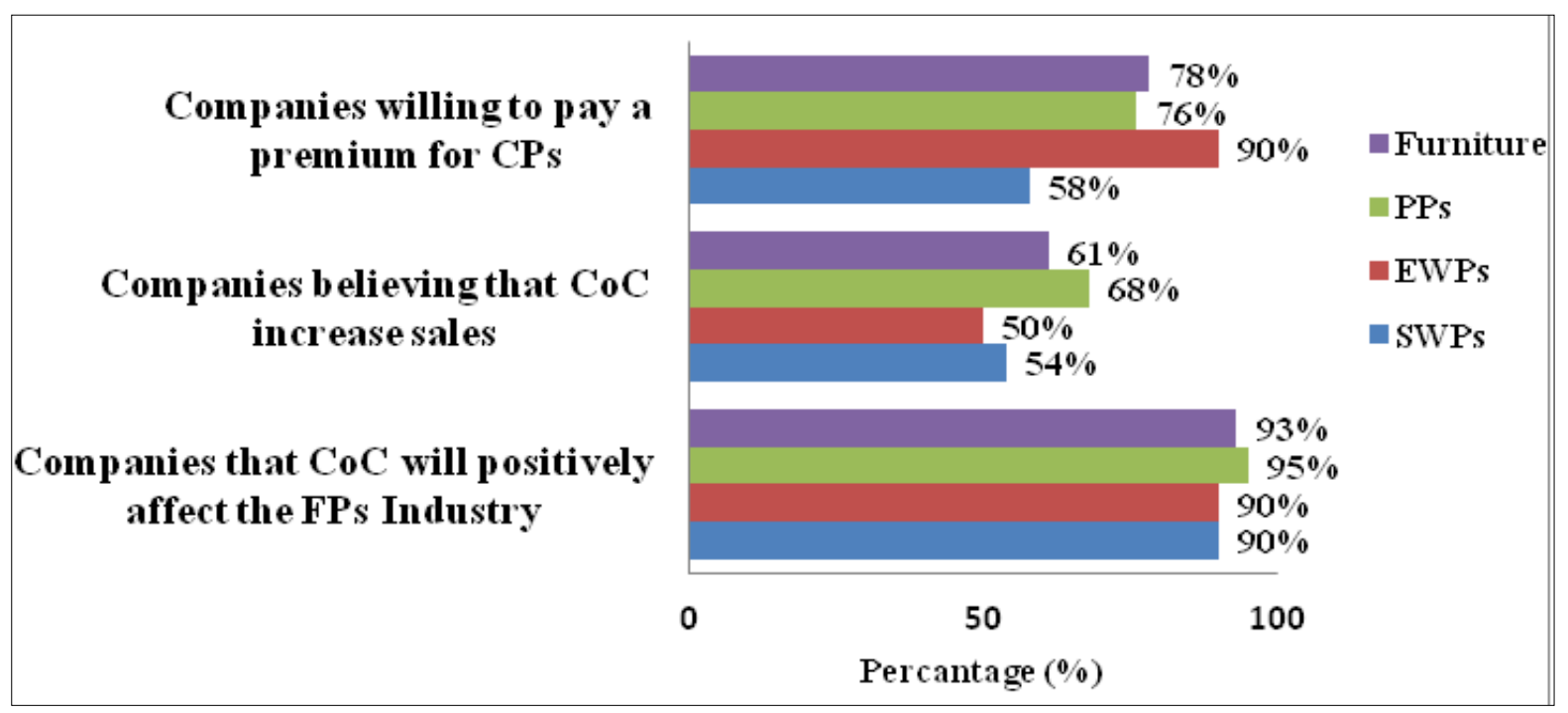

The companies interviewed believe it is worthy to promote the CoC certification, as it strives to support and develop SFM [3,9,23]. Because of this characteristic, companies would like to use CFPs.

The findings relating to sales problems experienced by companies due to the lack of a $\mathrm{CoC}$ are shown in Figure 6. The PPs manufacturers indicated that they were affected by the lack of a CoC certification at a rate of $25 \%$. This was followed by the furniture manufacturers with $13 \%$, SWPs manufacturers with $12 \%$ and EWPs manufacturers with $10 \%$. Forty percent of the companies were not affected by lack of a CoC.

The certificates requested from companies include either the FSC $\mathrm{CoC}$ with $14.7 \%$ or PEFC CoC certification with $6.2 \%$ and PEFC CoC certification with $2.3 \%$. No certificate was requested from $41.8 \%$ while the certificate of the International Organization for Standardization (ISO) and other various certificates were requested at a rate of $17.5 \%$. 
Figure 6. Companies experiencing sales problems due to lack of a $\mathrm{CoC}$.

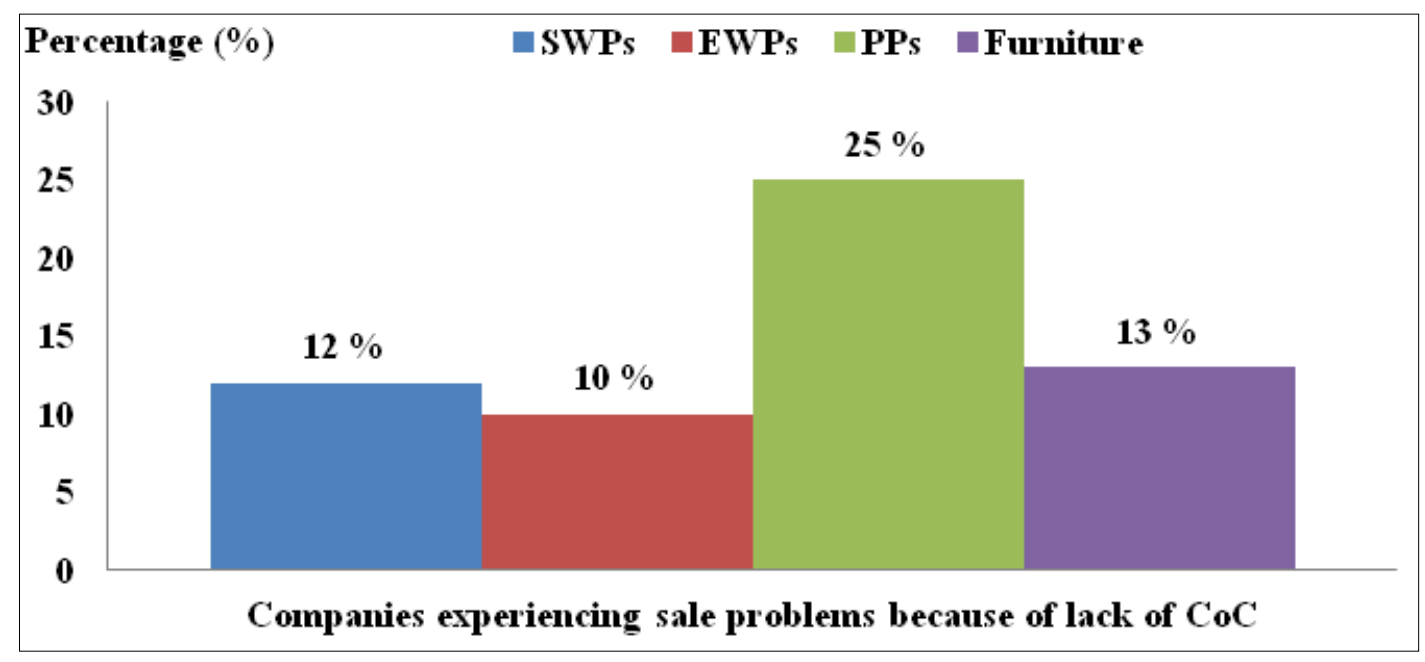

Figure 7. Certificates requested from companies.

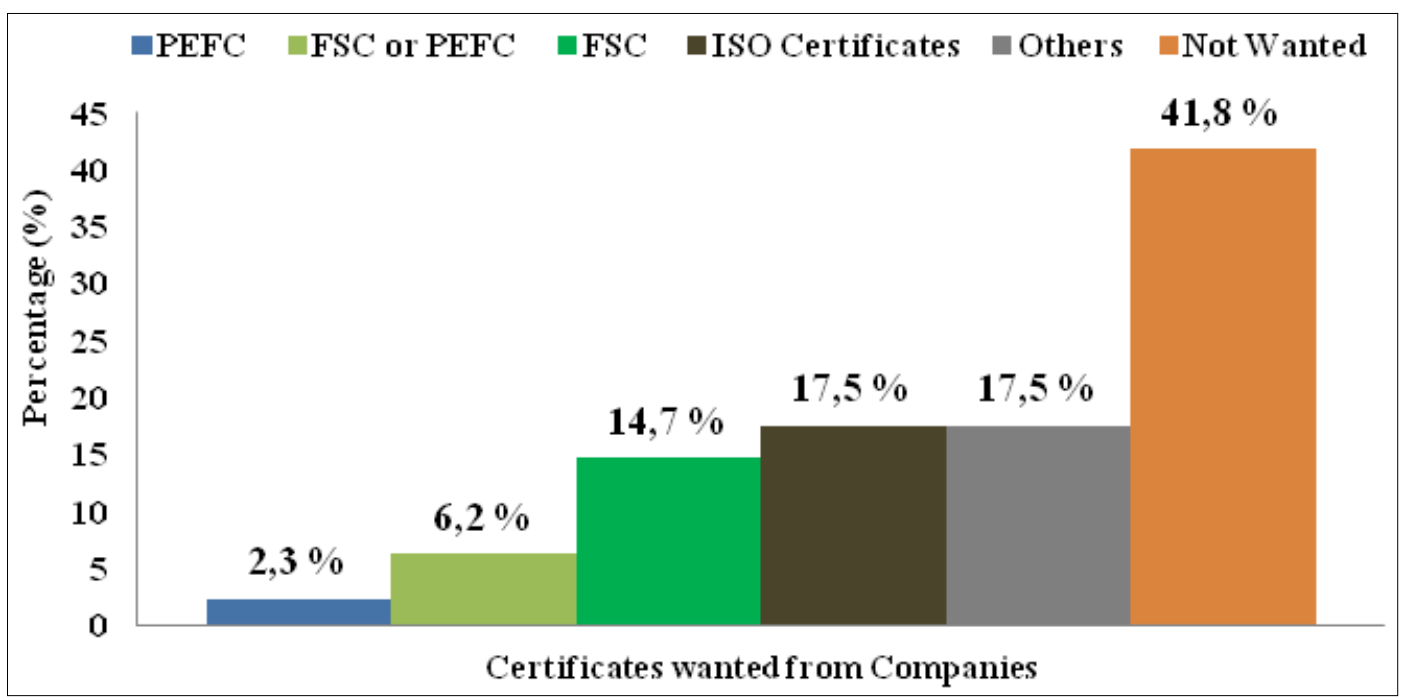

\section{Discussion}

Environmental marketing strategies are likely to see increased use as the global forest products industry recognizes the potential for competitive advantage. In order to be successful, the forest products industry must proactively build mechanisms for credible communication with consumers [27].

The findings show that the CoC certification system in Turkey is developing step by step. Results resembling these findings have also been observed in the studies conducted in other countries such as China [7], Canada [28] and the US [29]. The demand for CFPs, especially domestically, in Turkey is almost zero. Therefore, the CFPs market grows upon focusing on the export market. It is mandatory for companies to export, especially to European countries. They must have a $\mathrm{CoC}$ certification in order to enter the certified products market. Moreover the CFPs market will also develop in Turkey as consumers are becoming more environmentally conscious like in European countries.

In the study where the attitudes of Chinese wood products manufacturers towards forest certification were conveyed, certified companies recorded that this improved their market access and 
enhanced their company image and reputation. They also reported that forest certification could lead to better access to export markets and, to some extent, minimize or even eliminate barriers to trade, particularly in North American and European markets [7].

In the global furniture and related timber products industry the net effect of these changing demands of consumer pressure and changing taste is that a major responsibility has been thrown onto business. Companies in this industry have suddenly had to assume a new role with respect to environmental politics and the business environment has consequently undergone quite significant adaptation [3]. Wood producers must see that there is some economic advantage to participating in forest certification, whether the benefit consists of a price premium, maintenance of market access, lower costs of production, or protection or enhancement of market share. Thus, markets determine in part whether firms enter environmental agreements (certify their forest operations) without state involvement [30].

Companies accept the notion that long term benefits may be obtained in consequence to the corporate responsibility efforts displayed by CoC. Other benefits to be provided to the industry by the certificate included the potential for higher product quality, enhancement in the quality of management, competitive advantages over industry counterparts, the creation of an alternative advertisement and promotion tool, increased sales, higher prices, the need for remedial actions to be adopted in order to comply with requirements and long-term investment returns [7].

In this study, companies indicated that they are willing to pay a premium for CFPs. Availability of price premiums for certified products is an issue of continuous debate [31]. The amount of this payment carries a major importance. It was observed in the studies conducted on this topic that consumers may be willing to pay between $5-10 \%$, but that the number of willing consumers drops in the case of an increase in this rate [31,32]. A significant majority of the companies believe that the $\mathrm{CoC}$ certification will increase sales. In the surveys conducted it was indicated that $\mathrm{CoC}$ certification had a positive impact over sales [27]. However, there are some hesitations on whether the CoC certification will increase the profits of companies [25].

\section{Conclusion}

In this survey, where different perspectives and attitudes of SWPs, PPs, EWPs and furniture manufacturers towards the $\mathrm{CoC}$ certification system were investigated, face-to-face interviews were conducted with 177 company representatives where opportunity was obtained for discussing the certification system. The first company received its FSC CoC certification in Turkey in 2008. It was followed by four more companies in the same year. Eighteen more companies received their CoC certification in 2009 and this number reached 52 in 2010. A great majority of these companies were PPs manufacturers. It was revealed also by this survey that $\mathrm{CoC}$ certification was known mostly by the companies operating in this sector. Furniture manufacturers constitute the sector where the CoC certification is known least. Almost all of the companies included into this survey believe that certification is necessary in forest products and indicate that they prefer to use CFPs as they support responsible forestry. The companies recorded that even if the price of CFPs is high, they still would like to use them. The companies holding a $\mathrm{CoC}$ certificate believe that they will sell their products more easily and thus an increase will take place in sales. 
As the $\mathrm{CoC}$ certification will enable companies to produce environmentally friendly productions, it is believed that it will generate a positive impact on the industry. PPs constitute the product group where the CoC certification is most requested. Although a certificate is requested also from EWPs, SWPs and furniture manufacturers, this rate is not as high as it is in the pulp, paper and paperboard sector. The pulp, paper and paperboard sector is the field where the certificate is most widespread and where certified products are most requested. The $\mathrm{CoC}$ certification type most requested from companies in the Turkish forest products market is FSC CoC with a share of nearly $15 \%$. PEFC CoC has a share of nearly $2 \%$ while the rate of preference of either FSC CoC or PEFC CoC is $6 \%$. In this case, the CoC Certification which is most preferred in the Turkish forest products sector is FSC CoC. Meanwhile, the request level of the PEFC CoC certification is rather low.

It was observed in this study that the forest products companies in Turkey display a positive approach towards CFPs. This topic is regarded to be important for the sector due to the promotion of sustainable forest management implementations by the certificate. Especially large companies indicated that they would like to merchandize these products even if these have a high price. Also in the observations made in the warehouses of importing companies, it was seen that many timber batches imported from European countries were certified. Thus, it was understood that importing companies which met part of the need for forest products in our country, merchandized CFPs without noticing it. Although the request for CFPs does not reach very high levels, the certification system carries a major importance because it promotes the management of the forests across the world to be managed in accordance with universal management principles. It is clear that it will grow even further with the support of end-users and consumers in the industry.

\section{Acknowledgments}

This study is the summary of the $\mathrm{PhD}$ thesis prepared under the title, "The Timber Supplement to Forestry Industry in Respect to Sustainable Forest Management and Certification of Forest Products in Turkey" in Süleyman Demirel University (SDU) Graduate School of Natural and Applied Sciences and has been supported by SDU's Unit of Scientific Research Projects (Project No. 1912-D-09).

\section{Author Contributions}

Ahmet Tolunay designed the research, coordinated the data analysis and wrote to the paper. Türkay Türkoğlu conducted survey studies, helped him for statistical analysis and contributed to revising the manuscript.

\section{Conflicts of Interest}

The authors declare no conflict of interest.

\section{References}

1. Epinoza, O.; Buehlmann, U.; Smith, B. Forest certification and green building standards: overview and use in the U.S. hardwood industry. J. Clean. Prod. 2012, 33, 30-41. 
2. Schwarzbauer, P.; Rametssteiner, E. The impact of SFM-certification on forest product markets in Western Europe -an analysis using a forest sector simulation model. Forest Policy Econ. 2001, 2, 241-256.

3. Moris, M.; Dunne, N. Driving environmental certification: its impact on the furniture and timber products value chain in South Africa. Geoforum 2004, 35, 251-266.

4. Nebel, G.; Quevedo, L.; Jacobsen, J.; Helles, F. Development and economic significance of forest certification: the case of FSC in Bolivia. Forest Policy Econ. 2004, 7, 175-186.

5. Thompson, D.; Anderson, R.; Hansen, E.; Kahle, L. Green Segmentation and Environmental Certification: Insights from Forest products. Bus. Strat. Environ. 2009, 19, 319-334.

6. Rametsteiner, E.; Simula, M. Forest certification - an instrument to promote sustainable forest management? J. Environ. Manag. 2003, 67, 87-98.

7. Chen, J.; Innes, J.L.; Robert, A.K. An exploratory assessment of the attitudes of Chinese wood products manufacturers towards forest certification. J. Environ. Manag. 2011, 92, 2984-2992.

8. Vogt, K.A.; Larson, B.C.; Fanzeres, A. Forest Certification: Roots, Issues, Challenges, and Benefits; CRP Press Yale University: New Haven, CT, USA; pp. 11-20.

9. Cubbage, F.; Diaz, D.; Yapura, P.; Dube, F. Impacts of forest management certification in Argentina and Chile. Forest Policy Econ. 2010, 12, 497-504.

10. FSC. Available online: https://www.fsc.org/ (accessed on 10 September 2013).

11. PEFC. Available online: http://www.pefc.org/ (accessed on 11 September 2013).

12. Hubbard, S.S.; Bowe, S.A. Environmentally certified wood products: perspectives and experiences of primary wood manufactures in Wisconsin. Forest Prod. J. 2005, 55, 33-40.

13. Bratt, C.; Hallstedt, S.; Robèrt, K.H.; Broman, G.; Oldmark, J. Assessment of ecolabelling criteria development from a strategic sustainability perspective. J. Clean. Prod. 2011, 19, 1631-1638.

14. Upton, C.; Bass, S. The Forest Certification Handbook; St. Lucie Press: Delray Beach, FL, USA, 1996; p.18.

15. Türkoğlu, T.; Tolunay, A. Opinions related to certified forest products of forest products importer companies in Turkey. SDU Faculty of Forestry Journal 2013, 14, 95-101.

16. Türkoğlu, T. the timber supplement to forestry industry in respect to sustainable forest management and certification of forest products in turkey. Ph.D. thesis, Department of Forest Engineering, Graduate School of Applied and Natural Sciences at Süleyman Demirel University, Turkey, 2011; p. 243.

17. OGM. Available online: http://www.ogm.gov.tr/ (accessed on 5 September 2013).

18. Aksu, B.; Koç, K.H.; Kurtoğlu, A. The forest products industry in Turkey. Afr. J. Bus. Manag. 2011, 5, 2363-2369.

19. Sirtioğlu, I. 2010 Forest products Report for Turkey. Available online: http://gain.fas.usda.gov/ Recent\%20GAIN\%20Publications/2010\%20Forest\%20Products\%20Report\%20for\%20Turkey\% 20_Istanbul_Turkey_5-5-2010.pdf(accessed on 5 October 2013).

20. Bowyer, J. The green movement and the forest products industry. Forest Prod. J. 2008, 58, 6-13.

21. Ebeling, J.; Yasue, M. The effectiveness of market-based conservation in the tropics: forest certification in Ecuador and Bolivia. J. Environ. Manage. 2009, 90, 1145-1153. 
22. Cashore, B.; Gale, F.; Meidinger, E.; Newsom, D. Confronting Sustainability: Forest Certification in Developing and Transitioning Countries; Yale F\&ES Publication Series: New Haven, CT, USA, 2006; pp. 7-24.

23. Vlosky, R.P.; Ozanne, L.K. Environmental certification of wood products: The U.S. manufacturers' perspective. Forest Prod. J. 1998, 48, 21-26.

24. CRS. Available online: http://surveysystem.com/sscalc.htm/ (accessed on 20 November 2013).

25. Vidal, N.; Kozak, R.; Cohen, D. Chain of custody certification: An assessment of the North American solid wood sector. Forest Policy Econ. 2005, 7, 345-355.

26. Rickenbach, M.; Overdevest, C. More than markets: assessing Forest Stewardship Council (FSC) certification as a policy tool. J. Forest. 2006, 104, 143-147.

27. Hansen, E. Forest certification and its role in marketing strategy. Forest Prod. J. 1997, 47, 16-22.

28. Jayasinghe, P.; Allen, S.D.; Bull, G.Q.; Kozak, R.A. The status of forest certification in the Canadian value-added wood products manufacturing sector. Forestry Chron. 2007, 83, 113-125.

29. Vlosky, R.P.; Gazo, R.; Cassens, D. Certification involvement by selected United States value-added solid wood products sectors. Wood Fiber Sci. 2003, 35, 560-569.

30. Van Kooten, G.C.; Nelson, H.W.; Vertinsky, I. Certification of sustainable forest management practices: a global perspective on why countries certify. Forest Policy Econ. 2005, 7, 857-867.

31. Perera, P.; Vlosky, R.P.; Dunn, M.A.; Hughes, G.U.S. Home-center retailer attitudes, perceptions and attitudes regarding forest certification. Forest Prod. J. 2008, 58, 21-25.

32. Ozanne, L.K.; Vlosky, R.P. Willingness to pay for environmentally certified wood products: a consumer perspective. Forest Prod. J. 1997, 47, 39-48.

(C) 2014 by the authors; licensee MDPI, Basel, Switzerland. This article is an open access article distributed under the terms and conditions of the Creative Commons Attribution license (http://creativecommons.org/licenses/by/3.0/). 